\title{
Kryzys zaufania. Partycypacja społeczna i podsycanie konfliktów w procesie kształtowania środowiska miejskiego na przykładzie Krakowa
}

\section{Crisis of confidence. Social participation and stoking up conflicts in the process of shaping the urban environment on the example of Krakow}

\begin{abstract}
Streszczenie
Kraków i jego mieszkańców cechują rozbudzone aspiracje metropolitalne, jak również obawy i dążenia przypisywane raczej społecznościom średnich, a nawet małych ośrodków miejskich. Dumie ze statusu jednego z wiodących centrów akademickich nie zawsze towarzyszy zainteresowanie, a tym bardziej wiara w opinie autorytetów naukowych. Deklaracjom władz miejskich o tworzeniu klimatu sprzyjającego inwestycjom przeczą liczne wypowiedzi krakowian, w których określenia „biznesmen” czy „deweloper” stają się obraźliwymi epitetami. Autentycznemu wzrostowi znaczenia konsultacji społecznych w procesie planowania i rzetelnej ewaluacji zrealizowanych projektów przeciwstawia się swoista „kultura eskalacji konfliktów”. W podsycaniu antagonizmów niebagatelną rolę odgrywają internetowe fora i lokalne media, nierzadko przeczące swej koncyliacyjnej misji. Casus Krakowa nie wydaje się odosobniony - dlatego wnioski dotyczące zmniejszania podobnych mentalnych barier mogą okazać się przydatne także dla innych ośrodków miejskich.
\end{abstract}

Słowa kluczowe: Kraków, rozwój inteligentny, planowanie urbanistyczne

\begin{abstract}
Krakow and its inhabitants are characterized by both the awakened metropolitan aspirations, as well as fears and strivings which can be ascribed rather to the communities inhabiting medium and even small-sized urban centers. The pride derived from the status of one of the leading academic centers is not always accompanied by an interest in, and even less so, a belief in the opinion expressed by the academic authorities. The declarations of city authorities concerning the creation of a climate which promotes investment, are frequently being contradicted by numerous enunciations of Krakow citizens, in which terms, such as "businessman" or "developer" are meant to sound as offensive epithets. An authentic increase of the importance of social consultations accompanying the process of planning as well as a thorough evaluation of the realized projects is opposed by a specific "culture of escalation of conflicts". What plays a significant role in stoking up these antagonisms are, among others, the internet discussion forums and the local media which not infrequently contradict their conciliatory mission. The case of Krakow does not appear to be an exception; that is why, the conclusions concerning the decrease of similar mental barriers may turn out to be useful also to other urban centers.
\end{abstract}

Keywords: Krakow, intelligent development, urban planning 


\section{WPROWADZENIE}

Po zakończeniu w roku 2010 tzw. strategii lizbońskiej unijna strategia gospodarcza „Europa 2020” zakłada zrównoważony, inteligentny i sprzyjający włączeniu społecznemu model rozwoju ${ }^{1}$. Joanna Bach-Głowińska podkreśla fakt celowego rozróżnienia w tym dokumencie zapisu o zrównoważonym i inteligentnym rozwoju. „Zasadnicza różnica dotyczy aspektu związanego z partycypacją w procesie planowania. W procedurze zakładającej zrównoważony rozwój uczestnicy nie są równorzędni. Władza, eksperci, społeczność lokalna mają różne uprawnienia w trakcie trwania procedury i nie są one równoważne. Plan w związku z tym rzadko jest wyrazem kompromisu, raczej przeważają w nim interesy którejś ze stron. Natomiast w przypadku stosowania zasady inteligentnego rozwoju głównym celem staje się osiągnięcie kompromisu dla ustaleń planu. Równoważni są wszyscy uczestnicy - stają się współtwórcami przestrzeni, dla której powstaje plan. Oznacza to w konsekwencji, że uczestnicy biorą odpowiedzialność za ostateczny kształt planu”2. Strategia „Europa 2020” ma zatem charakter wybitnie prodemokratyczny oraz zgodny z unijną zasadą subsydiarności, tj. dążenia do podejmowania decyzji na jak najniższym szczeblu. Ponieważ jednak podejście do zagadnień zarządzania i szeroko pojmowanego planowania różni się w poszczególnych krajach członkowskich, z przyjętego dokumentu wynika, że „(...) model skandynawski - demokracji użytkownika, zostaje uznany za właściwy i jest obecnie promowany w całej Unii”3.

Cele zostały jasno określone. Może więc nie ma o czym dyskutować? Przykładowo, pracowników naukowych Wydziału Architektury Politechniki Krakowskiej nie trzeba przekonywać o modelowej wartości wielu współczesnych rozwiązań skandynawskich czy holenderskich. Znaczenie społeczności lokalnych w procesach planowania i projektowania oraz istotny wpływ sektora prywatnego na kształtowanie środowiska miejskiego również znajdują należne odzwierciedlenie w naukowym dyskursie. Dla krakowskiego samorządu zagadnienie szerokiej partycypacji społecznej także wydaje się stanowić priorytet. Z kolei przedstawiciele świata biznesu starają się na różne sposoby wpływać na przebieg procesów decyzyjnych lub też, czasem bez oglądania się na innych uczestników „gry o miasto”, samodzielnie kształtować obraz środowiska zbudowanego.

\section{STAN SPOŁECZEŃSTWA OBYWATELSKIEGO}

Jeśli naukowcy, członkowie samorządu i biznesmeni mają świadomość rzeczywistej czy choćby potencjalnej roli, jaką odegrać mogą w rozwoju miasta, „próba stworzenia modelu współpracy uczelni, samorządu i lokalnego biznesu" może wydawać się fraszką. Niestety, polskie realia szybko weryfikują zbyt optymistyczne założenia. W roku 1979 Stefan Nowak opublikował artykuł zatytułowany „System wartości społeczeństwa polskiego”. Dowodził w nim, że Polacy egzystują wyłącznie w dwóch wymiarach organizujących życie społeczne: 
na poziomie abstrakcyjnej wspólnoty narodowej oraz w sferze prywatności, zogniskowanej wokół rodziny i przyjaciół. Pomiędzy tymi biegunami rozciągać się miała tzw. próżnia socjologiczna, w której brakowało między innymi stowarzyszeń, obywatelskich inicjatyw i spontanicznych zachowań społecznych ${ }^{4}$. Krytycy tez profesora Nowaka dowodzą wprawdzie, że kłam zadał im „karnawał Solidarności” ze swymi 10 milionami uczestników. Jednak ten wielki ruch okazał się raczej zrywem na „poziomie narodowym” niż „silną wzajemnymi więzami wspólnotą obywateli"5.

Paradoksalnie, również fundamentalna transformacja ustrojowa 1989 roku nie przyniosła przełomowej poprawy w dziedzinie budowy społeczeństwa obywatelskiego. Powodem był głównie wybór wysoce indywidualistycznego, skrajnie konkurencyjnego modelu kapitalizmu, zapewniający szybki rozwój gospodarczy, lecz już niekoniecznie socjalny. Raport Diagnoza społeczna 2015, opracowany pod kierunkiem Janusza Czapińskiego i Tomasza Panka, bywa krytykowany za nadmierny optymizm. Natomiast jego rozdział poświęcony społeczeństwu obywatelskiemu budzić może jedynie grozę. Od działań i zainteresowań o charakterze wspólnotowym odżegnuje się aż 86,6\% Polaków! Tylko 13,4\% z nas deklaruje przynależność do „organizacji, stowarzyszeń, komitetów, rad, związków lub kół”. Jedynie 4\% obywateli udziela się w dwóch lub więcej tego rodzaju gremiach. Polska stanowi pod tym względem ewenement w skali europejskiej. Wyjątkowo niekorzystnie wypada porównanie z krajami skandynawskimi, które powinny stanowić dla nas wzorzec w dziedzinie planowania i kształtowania środowiska miejskiego. Tam ponad dwie trzecie obywateli wykazuje się społeczną aktywnością! W Niemczech ich liczba przekracza 50\%, a w krajach postkomunistycznych, jak Czechy, Węgry, Bułgaria i Rumunia, bywa nawet dwukrotnie wyższa niż w Polsce. Z brakiem poczucia odpowiedzialności za dobro wspólne idzie w parze zakorzeniona podejrzliwość. Również w tej „konkurencji” zajmujemy zdecydowanie ostatnie miejsce w Unii i niekorzystnie wyróżniamy się w skali globalnej. Tylko 12\% Polaków powyżej 16. roku życia ufa innym ludziom, a zaledwie $24 \%$ wierzy w uczciwość współobywateli. Przykładowo, w Danii odsetek ten wynosi odpowiednio 70 i 76\%! Niewiele mniejszym zaufaniem darzą się wzajemnie Finowie, Norwegowie, Holendrzy, Szwedzi, Niemcy. Nawet w Rosji jedna czwarta mieszkańców gotowa jest zaufać swym rodakom ${ }^{6}$.

Dlaczego jesteśmy dwadzieścia razy mniej aktywni społecznie od Skandynawów? Wydaje się to raczej stanowić rezultat trudnej przeszłości niż wad narodowego charakteru. Chlubna historia demokratycznych dążeń i pionierskich inicjatyw nie zrównoważy faktu, że gdy tworzyły się podwaliny nowoczesnych społeczeństw - Polska tkwiła w niewoli zaborców. Dwudziestolecie międzywojenne i ostatnie ćwierćwiecze okazały się okresem niewystarczającym do upowszechnienia i uwiarygodnienia działań o charakterze wspólnotowym - w zestawieniu z dwoma stuleciami jak najgorszych doświadczeń. Radykalna poprawa jest jednak możliwa. Zbigniew Bartuś pisze o praktycznym unieważnieniu na przestrzeni ostatnich lat określenia „Polnische Wirtschaft”, oznaczającego od czasów Bismarcka „bałagan, brak rzetelności i marną jakość” - podczas gdy obecnie Polacy uchodzą za „najsolidniejszych 
i najwydajniejszych pracowników Europy"7. Stałą, choć niełatwą, optymalizację procesów planowania i realizacji zrównoważonego środowiska miejskiego śledzić można na przykładzie Krakowa.

\section{GŁÓWNI „AKTORZY” WPŁYWAJĄCY NA JAKOŚĆ PRZESTRZENI WOKÓŁ NAS}

UCZELNIA - SAMORZĄD - BIZNES - tak przedstawia się wzorcowa triada partnerów w zamyśle równorzędnych, równoprawnych i współodpowiedzialnych za jakość środowiska miejskiego. Dążący do ideału obraz miasta mają zatem współtworzyć: rzetelni badacze, bezstronni eksperci, planiści i projektanci, kierujący się poczuciem dobra wspólnego, przedstawiciele społeczności lokalnej reprezentujący jej żywotne interesy oraz światli biznesmeni gotowi równoważyć chęć zysku i społeczny pożytek. Jednak już lektura tez pozwala dostrzec linię podziału, zarysowującą się między „samorządem” a „mieszkańcami”. Ci ostatni nie zawsze gotowi są utożsamiać się z inicjatywami „władz miejskich” różnego szczebla, podejmowanymi teoretycznie w ich imieniu ${ }^{8}$.

W „grę o miasto” włączają się dodatkowo jednostki i grupy przekonane o konieczności obrony interesów „zwykłych ludzi” i ich egzystencjalnej przestrzeni przed zakusami „rządzących”, „inwestorów” i działających na ich zlecenie „projektantów”. Jednocześnie przytłaczająca większość mieszkańców pozostaje obojętna na „toczące się obok” procesy planowania i działalność inwestycyjną. Ale ten brak reakcji skrywa raczej bierny opór niż milczącą akceptację przygotowywanych i realizowanych zmian. Źródła tego wszechogarniającego, nie zawsze przecież uzasadnionego braku zaufania sięgają bliższej i dalszej przeszłości, co sygnalizowano powyżej.

Kolejnym znaczącym „aktorem”, mającym bieżący wpływ na kształtowanie miejskiej przestrzeni, okazuje się w polskich realiach władza państwowa - zarówno ustawodawcza, jak i administracja rządowa. Przyczyny i charakter tych oddziaływań są zróżnicowane. Polska pozostaje wciąż jeszcze $w$ fazie transformacji, czego przejawem są częste zmiany obowiązujących ustaw i rozporządzeń. Niestety, równie ważnym powodem ich ciągłych modyfikacji jest niska jakość stanowionego prawa. Obowiązująca Konstytucja utrudnia samorządom ewentualne przeciwstawianie się władzy centralnej i nie gwarantuje możliwości pozyskiwania funduszy na realizację wszystkich powierzanych im zadań ${ }^{9}$. Ingerencje władz państwowych bywają wynikiem postulatów i oczekiwań samorządów miejskich, świata biznesu czy środowiska naukowego, ale mogą też stanowić próbę narzucenia niepopularnych rozwiązań bądź „upolitycznienia” pewnych procesów. Przykładem może być tu dobrze przyjęta Ustawa o związku metropolitarnym w województwie śląskim ${ }^{10}$, dająca podstawy rozwijania owocnej współpracy miast, oraz projekt ustawy metropolitalnej dla Warszawy, który niestety stał się przedmiotem politycznej rozgrywki ${ }^{11}$. Nadzieje i obawy związane z działaniami władz na szczeblu centralnym nie omijają również Krakowa. Miasto liczy na sfinansowanie północnej 
obwodnicy ${ }^{12}$, rozbudowy miejskiej kolei w ramach wojewódzkiego projektu Szybkiej Kolei Aglomeracyjnej ${ }^{13}$, linii metra ${ }^{14}$. Miejski samorząd od lat postuluje też zmiany w prawie, które umożliwiłyby wprowadzenie tzw. stref ekologicznych, czyli ograniczenia wjazdu do centrum pojazdów niespełniających określonych norm emisji spalin. Prezydent Krakowa wnioskował również o uwolnienie opłat w strefie ograniczonego postoju, tak by były one zróżnicowane w zależności od rejonu miasta ${ }^{15}$. Obecny projekt zmiany ustawy o drogach publicznych idzie w tym kierunku. Cel stanowi uwolnienie przestrzeni dla pieszych i rowerzystów, ograniczenie ruchu samochodowego i poprawa jakości powietrza ${ }^{16}$. Innym efektem takich zmian prawa krajowego byłoby powstrzymanie rozszerzania strefy płatnego parkowania, która obejmuje kolejne dzielnice Krakowa ${ }^{17}$. Mieszkańcy, władze samorządowe, planiści i biznesmeni wiążą wielkie nadzieje z szeroko konsultowanym projektem kodeksu urbanistyczno-budowlanego. Cele proponowanych regulacji są bardzo ambitne. Podstawowy stanowi „poprawa jakości przestrzeni w Polsce, czyli stworzenie rzeczywistego systemu planowania, który będzie uwzględniał potrzebę kształtowania ładu przestrzennego i umożliwiał zbilansowanie potrzeb społeczeństwa, gospodarki i środowiska". Wzmocnieniu ulec mają narzędzia planistyczne, takie jak studia uwarunkowań i kierunków zagospodarowania przestrzennego oraz plany miejscowe - ułatwiając wdrażanie idei miasta zwartego. Dla ośrodków historycznych, takich jak Kraków, istotna jest inicjatywa poszerzenia zakresu wszystkich planów o nowe elementy przydatne $w$ procesach rewitalizacji ${ }^{18}$. Nowy kodeks uprościć ma jednocześnie wymagania stawiane inwestorom indywidulanym, realizującym niewielkie obiekty, i uelastycznić procedury związane z przedsięwzięciami w skali makro. Grunty zarezerwowane w planach jako „obszary zorganizowanego inwestowania” (OZI) mają „czekać na firmy czy ich konsorcja, z którymi następnie mają być zawierane umowy urbanistyczne”. Realizacja takich inwestycji ma przebiegać szybciej i prościej niż w normalnym trybie i być dostosowana do konkretnych potrzeb zainteresowanego budową biznesu ${ }^{19}$. Jeszcze przed uchwaleniem kodeksu urbanistyczno-budowlanego przez Sejm RP krakowski samorząd na bieżąco reaguje na nadchodzące zmiany, przygotowując poprawki do obwiązującego Studium uwarunkowań i kierunków zagospodarowania przestrzennego miasta ${ }^{20}$. Również Ministerstwo Nauki i Szkolnictwa Wyższego oraz Ministerstwo Rozwoju przygotowują pakiet zmian prawnych i organizacyjnych, pośrednio faworyzujący inteligentny model współpracy nauki (uczelni) z biznesem i miejskimi samorządami. „Uczelnie muszą wziąć odpowiedzialność na otoczenie, w którym żyją" - jak to ujmuje Piotr Dardziński. Realizacji tego celu służyć ma otwarcie nowych ścieżek kariery akademickiej, bazujących na praktycznym wspieraniu badaniami konkretnych projektów i zamierzeń biznesowych ${ }^{21}$. Jednocześnie, jak już wspomniano, nie wszystkie inicjatywy władz centralnych budzą entuzjazm krakowskiego samorządu. Takim „nietrafionym prezentem” okazała się niedawna nowelizacja ustawy o ochronie przyrody, liberalizująca przepisy dotyczące usuwania drzew i krzewów z prywatnych posesji22. Nowe prawo, faworyzujące partykularne interesy właścicieli kosztem ogółu mieszkańców, doprowadziło do licznych nadużyć i dalszego uszczuplenia ubogiego drzewostanu Krakowa ${ }^{23}$. 
Liczne kontrowersje wzbudził też odgórnie forsowany pomysł ograniczenia do dwóch liczby kadencji prezydentów miast, wójtów i burmistrzów. Upolitycznienie dyskusji oraz zastrzeżenia w kwestii zgodności tego postulatu z Konstytucją RP powodują, że powrót do potrzebnej merytorycznej debaty nad ordynacją wyborczą do samorządów będzie utrudniony.

Wreszcie, last but not least, należy wymienić jeszcze jednego „aktora” pragnącego aktywnie współtworzyć obraz miasta - media. Lokalna prasa i telewizja rzadko dziś ograniczają się do prób bezstronnego przekazywania informacji, konkurując z Internetem i pomiędzy sobą na polu „interaktywności”. Stąd już niedaleko do prób wpływania na opisywane zjawiska, a nawet ich kreowania. Również „poważne” tytuły prasowe, takie jak „Dziennik Polski” i „Gazeta Wyborcza”, rywalizując o uwagę czytelników, wpadają czasem w pułapkę „tabloidyzacji", przejaskrawiając piętnowane zjawiska i dodatkowo zaogniając spory związane z kształtowaniem przestrzeni miejskiej.

A zatem: UCZELNIA - SAMORZĄD - BIZNES, lecz także: MIESZKAŃCY - RZĄD - MEDIA. Wpływy tej drugiej grupy warto dodatkowo uwzględnić przy „kształtowaniu i usprawnianiu modeli współpracy".

\section{KRAKÓW - OD ROZWOJU ZRÓWNOWAŻONEGO DO INTELIGENTNEGO}

Po półwieczu, jak to ujęła Jane Jacobs, „zamrożenia naturalnych mechanizmów ekonomicznych"24, panowania gospodarki nakazowo-rozdzielczej i statycznego myślenia o mieście, „przełom roku 1989 przywrócił bardziej żywiołowy charakter procesom urbanistycznym, poprzez odbudowę samorządu miejskiego i odblokowanie mechanizmów wolnorynkowych - ułatwione w Krakowie dzięki zachowaniu zrębów przedwojennej struktury własności". Proces kształtowania nowych, metodycznych i racjonalnych zasad rozwoju zaburzyła decyzja o unieważnieniu planów miejscowych, uchwalonych przed pierwszym stycznia 1995 roku²5. Niewykonalne zadanie bieżącego objęcia nowymi planami całego obszaru Krakowa uczyniło z nich spóźnione, a przez to często nieskuteczne narzędzie „interwencji kryzysowej”. Tereny o wyjątkowych walorach krajobrazowych oraz obszary strategiczne z punktu widzenia dalszego rozwoju miasta przez kolejne lata pozostawały bez pełnej ochrony, „wzbogacając się" o liczne kontrowersyjne inwestycje ${ }^{26}$. Jednak przykłady tworzenia nowego Studium uwarunkowań i kierunków zagospodarowania przestrzennego, kolejnych planów miejscowych, projektów rewitalizacji, a nawet wybranych inwestycji o charakterze czysto komercyjnym dowodzą możliwości skutecznego wdrożenia zasad zrównoważonego rozwoju. Symbolem niełatwych, lecz koniecznych kompromisów może być zarezerwowanie w Studium terenów w rejonie Rybitw (tzw. Nowego Miasta) pod krakowską dzielnicę wysokościowców, godzące skrajne postulaty obrońców krajobrazu i przedstawicieli wielkiego biznesu ${ }^{27}$. Jednocześnie nie można jeszcze mówić o powszechnej satysfakcji. Jak sygnalizowano we wstępie, uczestnikom procedur planistycznych, zakładających rozwój zrównoważony, nie zawsze gwarantuje 
się równe uprawnienia. Podmiotowego traktowania domagają się coraz częściej i głośniej lokalne społeczności i rady dzielnic, wobec których biznesmeni, miejskie władze, a nawet planiści usiłują stosować strategię faktów dokonanych. Gwałtowne protesty dotyczą problemów i miejsc tak odmiennych jak Nowa Huta, Podgórze, Kazimierz czy Stare Miasto ${ }^{28}$.

Mieszkańcy Krakowa oczekują kolejnej, jakościowej zmiany zasad kształtowania środowiska miejskiego. Zhierarchizowaną procedurę partycypacji społecznej, właściwą obecnemu modelowi planowania, pragną wzbogacić o egalitarne praktyki w duchu smart growth.

\section{PODSUMOWANIE}

UCZELNIA - SAMORZĄD - BIZNES - MIESZKAŃCY - RZĄD - MEDIA. Wszyscy ci „aktorzy” przekonani są o swej doniosłej roli w procesie kształtowania środowiska miejskiego Krakowa. Deklarują też najczęściej gotowość do debaty, lecz nie należy jej mylić ze skłonnością do kompromisu ani tym bardziej do ciągłej współpracy. Problem ten ma szczególny wymiar, ponieważ w Polsce odczuwalny jest dotkliwy brak ugruntowanej tradycji konstruktywnych dyskusji. Należy podkreślić, że za podsycanie wzajemnych antagonizmów odpowiadają w pewnej mierze wszyscy uczestnicy "gry o miasto”. Naukowcy i planiści, dysponujący fachową wiedzą, gotowi są tworzyć projekty jeszcze przed wysłuchaniem czyichkolwiek postulatów, zamieniając już wstępne spotkania „konsultacyjne” w jednostronne prezentacje. Przedstawiciele władz centralnych i samorządowych mylą własne opinie i pomysły z oczekiwaniami i wymaganiami miejskiej społeczności, podważając ideę partycypacji. (Przykładowo, radni dzielnicy Bieńczyce negowali sens aktywizacji mieszkańców i tworzenia budżetu obywatelskiego ${ }^{29}$, z kolei prezydent Jacek Majchrowski popiera konsultowanie przygotowanych przez miasto projektów, a nie już wstępnych idei, by zapobiec „zadyskutowaniu się na śmierć”30). Poczynania wielu biznesmenów i deweloperów cechuje arogancja i przekonanie, że rozwój miasta, tworzenie miejsc pracy i budowa mieszkań to ich wyłączna zasługa. W procesie kształtowania przestrzeni oczekują oni uprzywilejowanego traktowania lub samowolnie egzekwują należne ich zdaniem „prawa własności”, ignorując lub instrumentalizując społeczne konsultacje i zapisy planów. Media tworzą nie dającą się przecenić otwartą przestrzeń permanentnej debaty o mieście ${ }^{31}$, rzadziej jednak przyczyniają się do wypracowania kompromisu. Internetowe fora i tradycyjne środki przekazu „żyją konfliktem” lub „żyją z konfliktów”. Członkowie lokalnych społeczności, uchodzący często za bezbronne ofiary zakulisowych machinacji, potrafią też bezwzględnie forsować własne, partykularne interesy bądź niefrasobliwie dysponować cudzą własnością. Mieszkańcy nie ograniczają się do zgłaszania nurtujących ich problemów, lecz wbrew opiniom fachowców próbują narzucić irracjonalne sposoby ich rozwiązania. Zgłaszane przez nich postulaty są często całkowicie bezzasadne, a ponawiane protesty bywają też formą pospolitego szantażu angażujących znaczne środki finansowe biznesmenów. 


\section{WNIOSKI}

Paradoksalnie, pomimo tak licznych problemów i zastrzeżeń, należy stwierdzić, że inteligentny model współpracy na rzecz kształtowania zrównoważonego środowiska miejskiego powoli, lecz systematycznie toruje sobie drogę do świadomości krakowian oraz praktyki planistycznej i inwestycyjnej. Dążenie do ideału - budowania „miasta dla ludzi”32 na drodze kompromisu prawdziwie równorzędnych partnerów - nie wydaje się wymagać rewolucyjnych zmian. Wskazane jest raczej wyciąganie konstruktywnych wniosków z popełnianych dotychczas błędów. Taką korzystną ewolucję śledzić można na przykładzie zmieniającego się stosunku do zagadnień kształtowania i roli miejskiej zieleni ${ }^{33}$. Również w budżecie obywatelskim środki przeznaczane dotąd na projekty ogólnomiejskie przesuwane są do dzielnic - bliżej ludzi ${ }^{34}$. Naukowcy i studenci tworzą nowe narzędzia planistyczne, jak Atlas pokrycia terenu i przewietrzania Krakowa ${ }^{35}$, i przyjazne aplikacje, np. umożliwiające pasażerom ustalenie lokalizacji tramwajów ${ }^{36}$. Politechnika Krakowska wspiera magistrat, prowadząc pionierskie badania dotyczące zanieczyszczenia powietrza pyłem zawieszonym czy szkodliwości promieniowania elektromagnetycznego ${ }^{37}$. Znaczenie zyskują petycje i obywatelskie projekty uchwał kierowane do Rady Miasta ${ }^{38}$.

Podstawę do stworzenia ulepszonych procedur wielostronnej współpracy stanowić może, tworzona przez Komisję Dialogu Obywatelskiego przy Radzie Miasta Krakowa, „Biała Księga Dialogu Społecznego". Jest ona pomyślana jako zbiór zasad ich prowadzenia - ciekawszy, bardziej merytoryczny, angażujący nowych uczestników dzięki szerszemu wykorzystaniu narzędzi cyfrowych ${ }^{39}$. Budowanie Krakowa przyszłości i przyszłości innych miast na fundamencie wzajemnego szacunku i zaufania naprawdę wydaje się możliwe.

\section{PRZYPISY}

1 http://www/mg.gov.pl/Bezpieczeństwo+gospodarcze/Stategia+Europa+2020.

2 J. Bach-Głowińska, Inteligentna przestrzeń. Trzeci wymiar innowacyjności, Warszawa 2014, s. 39-40.

3 Ibidem, s. 40.

4 S. Nowak, System wartości społeczeństwa polskiego, „Studia Socjologiczne”, nr 4(75), 1979, s. 155-173.

5 Z. Bartuś, Polacy, naród wielki, społeczeństwo żadne, „Dziennik Polski”, 2 grudnia 2016.

6 J. Czapiński, Diagnoza społeczna 2015. Warunki i jakość życia Polaków - raport, „Contemporary Economics", 9/4, 2015, s. 332-372.

7 Z. Bartuś, op. cit.

8 A. Maj, Radni twierdzq, że chroniq zieleń, a tak naprawdę sprzyjajq inwestorom, „Dziennik Polski", 7 października 2016. 
9 W. Knap, Jakich zmian wymaga Konstytucja, „Dziennik Polski”, 5 maja 2017.

10 Dz.U. 2017, poz. 730.

${ }^{11}$ B. Burdzy, Warszawa zostanie powiększona? Trwa spór o władzę nad stolica, „Dziennik Polski", 12 lutego 2017.

12 P. Ogórek, Ważna umowa ws. północnej obwodnicy Krakowa, „Gazeta Wyborcza”, 9 stycznia 2017.

13 P. Tymczak, Prezydent próbuje udobruchać krakowian szybkq kolejq miejskq, „Dziennik Polski", 3 marca 2017.

${ }^{14}$ P. Setkowicz, Lekkie metro?, [w:] Węcławowicz-Bilska E. (red.), Nowe idee w planowaniu rozwoju terytorialnego. Wartości - przestrzenie - projekty, Monografia, Kraków 2017 (w przygotowaniu).

15 P. Tymczak, Europa zamyka centra dla aut. Kraków ma mniejsze możliwości, „Dziennik Polski", 10 marca 2017.

${ }^{16}$ P. Tymczak, Droższe parkowanie w centrum. Nawet 9 zł za godzinę postoju, „Dziennik Polski”, 17 marca 2017.

17 P. Ogórek, K. Janiszewska, Płatny postój - coraz większy, „Dziennik Polski”, 28 kwietnia 2017.

18 J. Michalczak, Rewitalizacja jest ważnym elementem zagospodarowania, „Dziennik Polski”, 30 listopada 2016.

19 J. Michalczak, Kodeks urbanistyczno-budowlany jeszcze w tym roku w Sejmie, „Dziennik Polski", 15 lutego 2017.

20 M. Mrowiec, Studium dla Krakowa do zmiany, „Dziennik Polski”, 7 grudnia 2016.

${ }^{21}$ Z. Bartuś, Nauka otworzy się na biznes, „Dziennik Polski”, 22 lutego 2017; Bartuś Z., Przychodzi nauka do biznesu, „Dziennik Polski”, 30 marca 2017.

22 Ustawa z dn. 16.12.2016 r. o zmianie ustawy o ochronie przyrody oraz ustawy o lasach, Dz.U. 2016, poz. 2249.

23 J. Michalczak, Nadużycia przy wycince, „Dziennik Polski”, 5 kwietnia 2017.

$24 \mathrm{~J}$. Jacobs, Cities and the Wealth of Nations. Principles of Economic Life, London 1986.

${ }^{25}$ W. Kosiński, Paradygmat miasta XXI wieku, Kraków 2016, s. 165-166.

${ }^{26}$ P. Setkowicz, Miejsce - przyjazne, pożq̨dane, zagrożone, [w:] Juzwa N., Sulimowska-Ociepka A. (red.), ULAR6. Odnowa krajobrazu miejskiego. Miasto-miejsca ludziom przyjazne. Idee - koncepcje - realizacje, T. 1, Monografia, Gliwice 2012, s. 375-378.

27 P. Setkowicz, Budynki wysokie w Krakowie - debata bez pointy, "Czasopismo Techniczne”, 3-A/2010, s. 195-202; Maj A., Kraków szuka w Cannes bogatych inwestorów, „Dziennik Polski", 17 marca 2017.

28 P. Setkowicz, Kraków - policentryczna metropolia czy niestabilna konurbacja?, [w:] Juzwa N., Sulimowska-Ociepka A. (red.), ULAR7. Odnowa krajobrazu miejskiego. Przyszłość miast średniej wielkości, T. 1, Monografia, Gliwice 2013, s. 507-511; Rogozik M., Konsultacje społeczne to fikcja. Udział mieszkańców jest niewielki, „Dziennik Polski”, 18 sierpnia 2016. 
${ }^{29}$ M. Rogozik, Bieńczyce już nie chcq budżetu obywatelskiego, „Dziennik Polski”, 17 stycznia 2017.

${ }^{30}$ A. Maj, P. Tymczak, Z ministrami rzq̨du PiS pracuje się lepiej niż z ich poprzednikami z PO, „Dziennik Polski”, 2 grudnia 2016.

${ }^{31}$ L. Peters, W poszukiwaniu recept dla Krakowa. Forum Gazety Wyborczej „Pracownia Miast”, „Nasza Politechnika”, nr 11 (135), 2014, s. 24-26.

32 J. Gehl, Miasta dla ludzi, Kraków 2014.

33 P. Tymczak, Radni liczq na pomoc mieszkańców w planowaniu terenów zielonych, „Dziennik Polski", 7 grudnia 2016.

${ }^{34}$ A. Maciejowski, M. Rogozik, Nowy budżet obywatelski; skorzystać majq wszyscy krakowianie, „Dziennik Polski”, 22 lutego 2017.

${ }^{35}$ www.obserwatorium.um.krakow.pl.

${ }^{36}$ mpk.jacekk.net.

37 A. Maj, Im więcej anten, tym większy smog?, „Dziennik Polski”, 15 lutego 2017.

38 A. Maj, Darmowe bilety dzięki petycji, „Dziennik Polski”, 23 grudnia 2016.

${ }^{39}$ P. Kopeć, Władze Krakowa zaprezentowały Biała Księgę Dialogu Społecznego, "Gazeta Wyborcza", 10 marca 2017; www.bip.krakow.pl.

\section{BIBLIOGRAFIA}

Bach-Głowińska J., Inteligentna przestrzeń. Trzeci wymiar innowacyjności, Warszawa 2014. Bartuś Z., Polacy, naród wielki, społeczeństwo żadne, „Dziennik Polski”, 2.12.2016.

Bartuś Z., Nauka otworzy się na biznes, „Dziennik Polski”, 22.02.2017.

Bartuś Z., Przychodzi nauka do biznesu, „Dziennik Polski”, 30.03.2017.

Burdzy B., Warszawa zostanie powiększona? Trwa spór o władzę nad stolicq, „Dziennik Polski", 2.02.2017.

Czapiński J., Diagnoza społeczna 2015. Warunki i jakość życia Polaków-raport, „Contemporary Economics", 9/4, 2015, s. 332-373.

Gehl J., Miasta dla ludzi, Kraków 2014.

Jacobs J., Cities and the Wealth of Nations. Principles of Economic Life, London 1986.

Knap W., Jakich zmian wymaga Konstytucja?, „Dziennik Polski”, 5.05.2017.

Kopeć P., Władze Krakowa zaprezentowały Białą Księgę Dialogu Społecznego, „Gazeta Wyborcza", 10.03.2017.

Kosiński W., Paradygmat miasta XXI wieku, Kraków 2016.

Maciejowski A., Rogozik M., Nowy budżet obywatelski: skorzystać majq wszyscy krakowianie, „Dziennik Polski”, 22.02.2017.

Maj A., Radni twierdzq, że chroniq zieleń, a tak naprawdę sprzyjajq inwestorom, „Dziennik Polski", 7.10.2016. 
Maj A., Tymczak P., Z ministrami rzq̨du PIS pracuje się lepiej niż z ich poprzednikami z PO, „Dziennik Polski”, 2.12.2016.

Maj A., Darmowe bilety dzięki petycji, „Dziennik Polski”, 23.12.2016.

Maj A., Im więcej anten, tym większy smog?, „Dziennik Polski”, 15.02.2017.

Maj A., Kraków szuka w Cannes bogatych inwestorów, „Dziennik Polski”, 17.03.2017.

Michalczak J., Rewitalizacja jest ważnym elementem zagospodarowania, „Dziennik Polski”, 30.11.2016.

Michalczak J., Kodeks urbanistyczno-budowlany jeszcze w tym roku w Sejmie, „Dziennik Polski", 15.02.2017.

Michalczak J., Nadużycia przy wycince, „Dziennik Polski”, 5.04.2017.

Mrowiec M., Studium dla Krakowa do zmiany, „Dziennik Polski”, 7.12.2016.

Nowak S., System wartości społeczeństwa polskiego, „Studia Socjologiczne”, nr 4(75), 1979, s. 155-173.

Ogórek P., Ważna umowa ws. północnej obwodnicy Krakowa, „Gazeta Wyborcza”, 9.01.2017. Ogórek P., Janiszewska K., Płatny postój - coraz większy, „Dziennik Polski”, 28.04.2017.

Peters L., W poszukiwaniu recept dla Krakowa. Forum Gazety Wyborczej „Pracownia Miast”, „Nasza Politechnika”, nr 11 (135), 2014, s. 24-26.

Rogozik M., Konsultacje społeczne to fikcja, udział mieszkańców jest niewielki, „Dziennik Polski", 18.08.2016.

Rogozik M., Bieńczyce już nie chcq budżetu obywatelskiego, „Dziennik Polski”, 17.01.2017.

Setkowicz P., Budynki wysokie w Krakowie - debata bez pointy, "Czasopismo Techniczne”, 3-A/2010, s. 195-202.

Setkowicz P., Miejsce - przyjazne, pożq̨dane, zagrożone, [w:] Juzwa N., Sulimowska-Ociepka A. (red.), ULAR6. Odnowa krajobrazu miejskiego. Miasto - miejsca ludziom przyjazne. Idee - koncepcje - realizacje, T. 1, Monografia, Gliwice 2012, s. 375-378.

Setkowicz P., Kraków - policentryczna metropolia czy niestabilna konurbacja?, [w:] Juzwa N., Sulimowska-Ociepka A. (red.), ULAR7. Odnowa krajobrazu miejskiego. Przyszłość miast średniej wielkości, T. 1, Monografia, Gliwice 2013, s. 507-511.

Setkowicz P., Lekkie metro?, [w:] Węcławowicz-Bilska E. (red.), Nowe idee w planowaniu rozwoju terytorialnego. Wartości - przestrzenie - projekty, Monografia, Kraków 2017.

Tymczak P., Radni liczq na pomoc mieszkańców w planowaniu terenów zielonych, „Dziennik Polski", 7.12.2016.

Tymczak P., Prezydent próbuje udobruchać krakowian szybkq kolejq miejskq, „Dziennik Polski”, 3.03.2017.

Tymczak P., Europa zamyka centra dla aut. Kraków ma mniejsze możliwości, „Dziennik Polski”, 10.03.2017.

Tymczak P., Droższe parkowanie w centrum. Nawet 9 zł za godzinę postoju, „Dziennik Polski”, 17.03.2017. 
Ustawa z dn. 16.12.2016 r. o zmianie ustawy o ochronie przyrody oraz ustawy o lasach, Dz.U. 2016, poz. 2249.

Ustawa z dn. 9.03.2017 o związku metropolitalnym w województwie śląskim, Dz.U. 2017, poz. 730.

mpk.jacekk.net (access: 25.07.2017).

www.bip.krakow.pl (access: 25.07.2017).

www.mg.gov.pl/Bezpieczeństwo+gospodarcze/Stategia+Europa+2020 (access: 25.07.2017). www.obserwatorium.um.krakow.pl (access: 25.07.2017). 